\title{
低濃度二酸化炭素施用が促成栽培キュウリの収量に及ぼす影響とその経済性評価
}

\author{
川城英夫 ${ }^{1 *} \cdot$ 土屋 $\quad$ 和 $^{2 \mathrm{a}} \cdot$ 崎山 $-^{3} \cdot$ 宇田川雄二 ${ }^{1}$ \\ 1 千葉県農林総合研究センター 266-0006 千葉市緑区大膳野町 \\ ${ }^{2}$ 太洋興業株式会社 103-0004 東京都中央区東日本橋 \\ 3 千葉県農林水産部 260-8667 千葉市中央区市場町
}

\section{Effects of Low-concentration Carbon Dioxide Supplementation on Fruit Yield and Economic Value of Cucumber on Forced Culture}

\author{
Hideo Kawashiro $^{1 *}$, Kazuo Tsuchiya ${ }^{2}$, Hajime Sakiyama ${ }^{3}$ and Yuji Udagawa ${ }^{1}$ \\ ${ }^{1}$ Chiba Prefectural Agriculture and Forestry Research Center, Daizenno, Midori-ku, Chiba 266-0006 \\ ${ }^{2}$ Taiyo Kogyo Company, Limited, Higashinihonbashi, Chuo-ku, Tokyo 103-0004 \\ ${ }^{3}$ Chiba Prefecture Agricurture, Forestry and Fisheries Department, Ichiba, Chuo-ku, Chiba 260-8667
}

\begin{abstract}
The responses of cucumber on forced culture involving a range of carbon dioxide concentrations and length of supplementation times in a greenhouse, a long-term supplementation from 7:30 a.m. to 14:30 p.m. at 500 ppm, and a short-term supplementation from 7:30 a.m. to 10:30 a.m. at 1,000 ppm, were examined together with those on non-enriched treatment. Both carbon dioxide enrichments increased the marketable fruit yield by 39-55\%. Even if expenditure due to carbon dioxide enrichment is subtracted, the gross return was 58,000-96,000 yen per $100 \mathrm{~m}^{2}$ higher than non-enriched culture. In the long-term supplementation the growth yield was larger, and the amount of carbon dioxide used was less than in the short-term supplementation. Long-term supplementation at $500 \mathrm{ppm}$ was cost-effective.
\end{abstract}

Key Words : net assimilation rate, relative growth rate

キーワード：純同化率，相対生長率

\section{緒 言}

我が国に打ける野菜の施設栽培では, 増収を目的として 冬季に栽培する果菜類を中心に二酸化炭素施用が行われて いる（大須賀，2003）。高温・高湿度管理を行らキュウリ (Cucumis satius L.) の促成栽培では, 換気時間が短く, 換 気空および内張りカーテンの開度も小さいために晴天日の 日中には二酸化炭素飢餓が起こりやすく, その対策として 二酸化炭素施用が行われ, 高い増収効果が得られている (板木, 1983; Slack・Hand, 1985, 1986).

施設栽培キュウリに対する我が国の二酸化炭素施用基準 は, 日の出 30 分後から換気を開始するまでの $2 \sim 3$ 時間, 晴天時で $1,000 \sim 1,500 \mathrm{ppm}$, 量天時で $500 \sim 1,000 \mathrm{ppm}$ と されている（大須賀，2003）。これは, 本基準の二酸化炭素 濃度の範囲に通常の栽植密度および日射量に拈ける二酸化

2008 年 10 月 3 日 受付. 2009 年 3 月 10 日 受理.

本報告の一部は園芸学会平成 18 年度秋季大会で発表した.

* Corresponding author. E-mail: h.kwshr@mc.pref.chiba.lg.jp

a 現在 : MKV ドリーム株式会社
炭素飽和点があり（伊東，1973），増収効果も高い（Slack・ Hand, 1985, 1986）ことによる. また，植物が日射を受けて から気孔が全開するまでに $30 〜 50$ 分を要すること，晴れ た日では日の出後 $30 \sim 40$ 分経過した頃に光合成が盛んに なって施設内の二酸化炭素濃度が急激に減少すること（伊 東，1970，1971，1973，1977），換気をともな5日中に二酸化 炭素を施用しても室外に散逸して不経済である（伊東， 1977; 渡辺・上浜，1976）との考えに基ついて，施用時間 が設定されている.

一方，換気を行っている時間帯でも，作物の群落内およ び葉面周辺では二酸化炭素濃度が大気より低下すること （伊東，1970, 1971; Slack・Hand, 1985）から, 換気後も二酸 化炭素を施用すれば物質生産が促進され，さらに増収する 可能性があると推察される。 また，オランダなどで行われ ているように大気中の濃度よりやや高い $500 \sim 800$ ppm 程 度に二酸化炭素を施用すれば，換気による室外への二酸化 炭素放出割合が低下し，施用した二酸化炭素の利用率は高 まると考兄らる（Kamp・Timmerman, 2004）. Slack・Hand （1985）は，換気が頻繁に行われる夏季の施設栽培でも二酸 化炭素濃度を $450 \mathrm{ppm}$ に高めることによってキュウリの果 
実収量が $22 \%$ 増加し, 費用対効果が高いことを報告してい る. これらのことから, 低濃度の二酸化炭素を換気中にも 施用する方法は, $1,000 \mathrm{ppm}$ 前後で短時間施用する方法に 比べてキュウリの増収効果が高く, 二酸化炭素の室外への 散逸が少ない経済的な施用法ではないかと考えた.

本研究は, 大気中の濃度よりやや高い $500 \mathrm{ppm}$ を目標に 二酸化炭素を換気中にも施用する管理法が，促成栽培キュ ウリの生育と果実収量に及ぼす影響を明らかにするととも に，その経済性評価を行らことを目的とした。

\section{材料および方法}

\section{1. キュウリの果実収量に及ぼす二酸化炭素施用の影響}

試験は, 間口 $4.8 \mathrm{~m}$, 奥行 $7 \mathrm{~m}$, 棟高 $3.3 \mathrm{~m}$ で, 1 室 $33.6 \mathrm{~m}^{2}$ のガラス温室で実施した. 内部に厚さ $0.01 \mathrm{~mm}$ の農業用ビ ニルで内張りカーテンを設置し, 高さ $53 \mathrm{~cm}$ の高設床で栽 培した. 穂木は“八イグリーン 21’（(株）埼玉原種育成会), 台木は“ひかりパワーゴールド”（(株）ときわ研究場）を供 試した。

試験区は, 7 時 30 分〜 14 時 30 分までの 7 時間にわたっ て二酸化炭素濃度を $500 \mathrm{ppm}$ に制御する $500 \mathrm{ppm}$ 区，7時 30 分〜 10 時 30 分までの 3 時間を $1,000 \mathrm{ppm}$ に制御する $1,000 \mathrm{ppm}$ 区, 無施用区の 3 区設け, 1 区 10 株 3 反復とした.

穂木は 2003 年 10 月 22 日, 台木は 10 月 23 日に播種, 11 月 4 日に呼び接ぎを行い，11月 20 日に 2 葉期苗を，株間 $20 \mathrm{~cm}, 417$ 株・ $\mathrm{a}^{-1}$ で定植した. 主枝は 6 節までの雌花お よび子蔓を摘除し，7 節目から出た子蔓を 1 本放任枝とし た. 他の子曼は 1 節で摘心, 主枝は 13 節で摘心した. 室温 は 13 時 30 分まで $29^{\circ} \mathrm{C}$, 以後 15 時まで $25^{\circ} \mathrm{C}, 16$ 時 30 分 まで $22^{\circ} \mathrm{C}$ で天空を開閉し, 夜間は $13^{\circ} \mathrm{C}$ に加温した。 天 空の開閉抢よび加温は, Green Kit 102 （株）イー・エス・ ディ）で制御した。内張りカーテンは 2 月 20 日までは 11 時 30 分に, それ以降は 10 時 30 分に $10 \mathrm{~cm}$ 開け, 16 時 30 分に閉じた. 施肥は, 基肥として窒素 $2.5 \mathrm{~kg} \cdot \mathrm{a}^{-1}$, リン酸 $3.3 \mathrm{~kg} \cdot \mathrm{a}^{-1}$, 加里 $2.5 \mathrm{~kg} \cdot \mathrm{a}^{-1}$ 施用した. その他の管理は慣 行に準じた.

二酸化炭素は液化二酸化炭素を用い, 高さ $1.0 \mathrm{~m}$ の位置 に 1 室 2 本, 小孔を開けたビニルチューブを設置して施用 した. 12 月 19 日，7節目の雌花開花期に二酸化炭素施用を 開始し，収穫終了日まで施用した。二酸化炭素は，各区の 設定值以下になったら $500 \mathrm{ppm}$ 区は 1 度に 1 分間, 1,000 ppm 区は 1 月 9 日までは 1 度に 1 分間, 1 月 10 日以降は設定 濃度を維持するために同 2 分間放出した. キュウリ群落内 の二酸化炭素濃度は, 赤外線二酸化炭素分析計 Ventpstat （(株）TELAIRE）で測定した. キュウリの果実は 2003 年 1 月 1 日〜 3 月 10 日まで毎日収穫し, 粗収益は月別上物収量 に $1999 \sim 2003$ 年の東京都中央卸売市場の月別平均単価を 乗じて算出した.

\section{2. キュウリ幼植物の生育, 乾物生産に及ぼす二酸化炭素 施用の影響}

試験は，前述のガラス室で実施した。 2003 年 2 月 17 日 に培養土げんきくん果菜 200 （(株）コープケミカル）を詰 めた播種箱に播種し, 播種 12 日後に本葉未展開のキュウリ 苗を播種箱から抜いて根を水洗し, 崎山ら（2001）の方法 に準じて育苗装置に移植して養液栽培を行った，培養液は 大塚 $\mathrm{A}$ 処方（池田，1996）の $3 \cdot 4^{-1}$ 濃度（EC $2.0 \mathrm{dS} \cdot \mathrm{m}^{-1}$ ) を用いた. 移植 14 日後の 3 月 15 日にキュウリ 3.5 葉期苗 を 1 株ずつ上記培養液を満たした $1 \cdot 5,000 \mathrm{a}^{-1}$ ワグネルポッ トに鉢上げし，前述したガラス室の各処理区に各区 7 株搬 入して二酸化炭素処理を開始した。 培養液は, エアーポン プによって常時通気処理を行い, 処理 7 日後の 3 月 22 日に 生育中庸な 5 株の生育量, 乾物重を調査した。

\section{結果}

\section{1. 温室内二酸化炭素濃度}

晴天となった 2003 年 2 月 5 日に打ける無施用区の温室内 二酸化炭素濃度は，8 時頃から低下し始め，9時に $300 \mathrm{ppm}$ を下回り，最低濃度は $171 \mathrm{ppm}$ となった。 9 時〜 16 時 30 分までの平均濃度は $223 \mathrm{ppm}$ であった。 $500 \mathrm{ppm}$ 区では, 二酸化炭素施用開始 10 分後の 7 時 40 分から施用を終了し た 14 時 30 分までの平均二酸化炭素濃度は $563 \mathrm{ppm}$ であっ た. $1,000 \mathrm{ppm}$ 区では，二酸化炭素施用開始 10 分後の 7 時 40 分から施用を終了した 10 時 30 分までの平均二酸化炭素 濃度は $935 \mathrm{ppm}$ で，二酸化炭素施用中止後には $270 \mathrm{ppm}$ に まで低下した，500 および 1,000 ppm 区の二酸化炭素濃度 は，16 時まで無施用区より高かった（第 1 図).

\section{2. キュウリの果実収量}

収穫期間を通して二酸化炭素施用区は，無施用区に対し て上物収量, 総収量ともに多かった。 上物収量は最も多収 となった $500 \mathrm{ppm}$ 区が無施用区の $155 \%$ となり，1,000 ppm 区は同 $139 \%$ となった。総収量も同様で，二酸化炭素施用 区は無施用区の $135 \sim 150 \%$ と，大幅な増収となった.

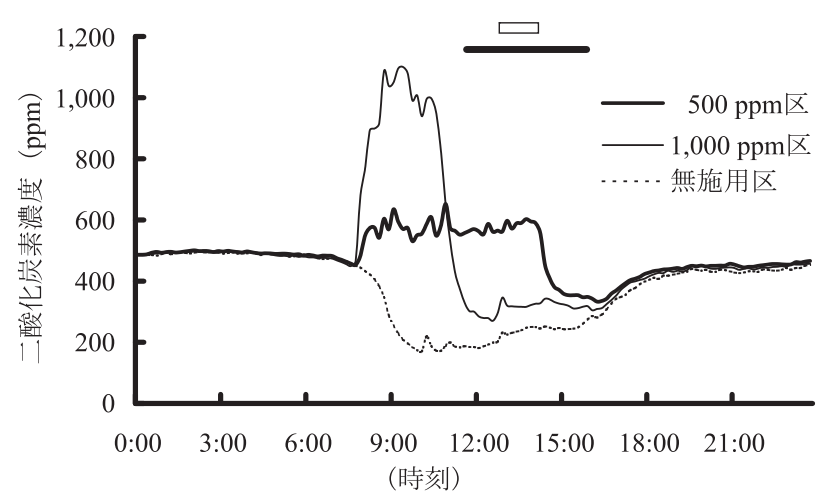

第 1 図 温室内二酸化炭素濃度の日変化 (2003 年 2 月 5 日, 晴) 凹は天空が開いている時刻を示す

—は内張りカーテンが開いている時刻を示す 
第 1 表 二酸化炭素施用が促成栽培キュウリの果実収量に及ぼす影響

\begin{tabular}{|c|c|c|c|c|c|c|c|c|}
\hline \multirow{3}{*}{ 試験区 } & \multicolumn{8}{|c|}{ キュウリの果実収量 $\left(\mathrm{kg} \cdot \mathrm{a}^{-1}\right)$} \\
\hline & \multicolumn{2}{|c|}{1 月 } & \multicolumn{2}{|c|}{2 月 } & \multicolumn{2}{|c|}{3 月 } & \multicolumn{2}{|c|}{ 合計 } \\
\hline & 上物 ${ }^{\mathrm{z}}$ & 総収量 & 上物 & 総収量 & 上物 & 総収量 & 上物 & 総収量 \\
\hline $500 \mathrm{ppm}$ & $445 b^{y}$ & $484 \mathrm{~b}$ & $394 \mathrm{~b}$ & $458 \mathrm{~b}$ & $163 \mathrm{~b}$ & $184 \mathrm{~b}$ & $1,002 \mathrm{c}(155)$ & $1,126 \mathrm{c}(150)$ \\
\hline $1,000 \mathrm{ppm}$ & $390 \mathrm{~b}$ & $421 \mathrm{~b}$ & $377 \mathrm{~b}$ & $445 \mathrm{~b}$ & $136 \mathrm{~b}$ & $147 \mathrm{~b}$ & $903 \mathrm{~b}(139)$ & $1,012 \mathrm{~b}$ \\
\hline 無施用 & $247 \mathrm{a}$ & $281 \mathrm{a}$ & $303 \mathrm{a}$ & $359 \mathrm{a}$ & $98 \mathrm{a}$ & $108 \mathrm{a}$ & $648 \mathrm{a}(100)$ & $749 \mathrm{a}(100)$ \\
\hline
\end{tabular}

${ }^{\mathrm{z}}$ 上物は, 曲がり $3 \mathrm{~cm}$ 未満の果実の合計収量

$\mathrm{y}$ 同一列の異なる文字は Tukey-Kramer 法により 5\%水準で有意差があることを示す

第 2 表 キュウリ栽培期間中の二酸化炭素施用量 (推定)

\begin{tabular}{|c|c|c|c|}
\hline 項目 & 時期 & $500 \mathrm{ppm}$ 区 & $1,000 \mathrm{ppm}$ 区 \\
\hline & 12 月 19 日〜 31 日 & 21 & 22 \\
\hline 二酸化炭素 & 1 月 1 日 31 日 & 59 & 70 \\
\hline 施用量 & 2 月 1 日 29 日 & 64 & 70 \\
\hline \multirow[t]{2}{*}{$\left(\mathrm{kg} \cdot \mathrm{a}^{-1}\right)$} & 3 月 1 日 10 日 & 26 & 25 \\
\hline & 合計 & 170 & 187 \\
\hline \multicolumn{2}{|c|}{$\begin{array}{l}1 \text { 日当たり二酸化炭素施用量 } \\
\left(\mathrm{kg} ・ \text { 日 }^{-1}\right)\end{array}$} & 3.1 & 3.5 \\
\hline
\end{tabular}

第 3 表 二酸化炭素施用の経済性に関係する各指標值

\begin{tabular}{|c|c|c|c|}
\hline 項目 & 500 ppm 区 & $1,000 \mathrm{ppm}$ 区 & 無施用区 \\
\hline $\begin{array}{l}\text { キュウリ上物収量 } \\
\left(\mathrm{kg} \cdot \mathrm{a}^{-1}\right)\end{array}$ & 1,002 & 903 & 648 \\
\hline $\begin{array}{l}\text { キュゥリ粗収益 } \\
\left(円 ・ a^{-1}\right)^{z}\end{array}$ & 355,200 & 319,800 & 227,300 \\
\hline $\begin{array}{l}\text { 二酸化炭素施用による } \\
\text { 粗収益増 }\left(\text { 円・ } \mathrm{a}^{-1}\right) \mathrm{y}\end{array}$ & 127,900 & 92,500 & - \\
\hline $\begin{array}{l}\text { 二酸化炭素施用装置一式 } \\
\left(\text { 円 } \mathrm{a}^{-1}\right)\end{array}$ & 40,000 & 40,000 & - \\
\hline $\begin{array}{l}\text { 二酸化炭素施用装置 } \\
\text { 償却年数（年） }\end{array}$ & 5 & 5 & - \\
\hline $\begin{array}{l}\text { 二酸化炭素施用装置減価 } \\
\text { 償却費 }\left(\text { 円 } \mathrm{a}^{-1} \cdot \text { 年 }^{-1}\right)\end{array}$ & 8,000 & 8,000 & - \\
\hline $\begin{array}{l}\text { 液化二酸化炭素施用量 } \\
\left(\mathrm{kg} \cdot \mathrm{a}^{-1}\right)\end{array}$ & 170 & 187 & - \\
\hline $\begin{array}{l}\text { 液化二酸化炭素単価 } \\
\left(\text { 円・ } \mathrm{kg}^{-1}\right)\end{array}$ & 140 & 140 & - \\
\hline $\begin{array}{l}\text { 液化二酸化炭素施用代 } \\
\left(\text { 円 } \mathrm{a}^{-1}\right)\end{array}$ & 23,800 & 26,180 & - \\
\hline
\end{tabular}

zキュウリの月別上物収量に, 1999 2003 年までの東京都中 央卸売市場の月別単価を乗じて算出した

y 二酸化炭素酸施用区粗収益 - 無施用区粗収益の値を示した
第 4 表 促成栽培キュウリに対する二酸化炭素施用の経済性 $\left(\right.$ 円 $\left.a^{-1}\right)$

\begin{tabular}{lrr}
\hline \hline & $500 \mathrm{ppm}$ 区 & $1,000 \mathrm{ppm}$ 区 \\
\hline 二酸化炭素施用による粗収益増 & 127,900 & 92,500 \\
二酸化炭素施用に要する経費 & 31,800 & 34,280 \\
(二酸化炭素施用装置減価償却費) & 8,000 & 8,000 \\
(液化二酸化炭素代) & 23,800 & 26,280 \\
\hline 差し引き収益増 & 96,100 & 58,220 \\
\hline
\end{tabular}

二酸化炭素施用区間では, 上物収量, 総収量ともに500 ppm 区が $1,000 \mathrm{ppm}$ 区に対して $15 \sim 16 \%$ 多かった（第 1 表）.

\section{3. 二酸化炭素施用の経済性}

二酸化炭素施用チューブから放出される時間当たり二酸 化炭素放出量を試験区ごとに測定し，各区の二酸化炭素放 出時間から二酸化炭素施用量を推定した。 その結果，栽培 期間中の二酸化炭素施用量は， $500 \mathrm{ppm}$ 区が $170 \mathrm{~kg} \cdot \mathrm{a}^{-1}$, $1,000 \mathrm{ppm}$ 区が $187 \mathrm{~kg} ・ 10 \mathrm{a}^{-1}$ となり, $500 \mathrm{ppm}$ 区は $1,000 \mathrm{ppm}$ 区の 2 倍以上の時間施用しているにもかかわらず二酸化炭 素施用量は $9 \%$ 少なかった（第 2 表）.

二酸化炭素施用によるキュウリの収量増に伴ら粗収益増 は, $500 \mathrm{ppm}$ 区が 127,900 円・ $\mathrm{a}^{-1}, 1,000 \mathrm{ppm}$ 区が 92,500 円・ $\mathrm{a}^{-1}$ となり, これから二酸化炭素施用に伴う施用装置の減価 償却費, 施用した液化二酸化炭素代を差し引いた収益増は, $500 \mathrm{ppm}$ 区が 96,100 円・a $\mathrm{a}^{-1}, 1,000 \mathrm{ppm}$ 区が 58,220 円・10 $\mathrm{a}^{-1}$ となった（第 $3 ， 4$ 表).

\section{4. キュウリ幼植物の生育, 乾物生産}

処理開始後 7 日目のキュウリの生育量は, 葉面積, 各器 官の生体重，乾物重とも，500 ppm 区が最も大きく，次い で $1,000 \mathrm{ppm}$ 区となり，無処理区が最も小さい傾向を示し た(第 5 表). 乾物重の相対生長率も, $500 \mathrm{ppm}$ 区が $1,000 \mathrm{ppm}$

第 5 表 二酸化炭素施用がキュウリ幼植物の生育に及ぼす影響 $\mathrm{z}$

\begin{tabular}{|c|c|c|c|c|c|c|c|c|c|c|c|c|}
\hline \multirow{2}{*}{ 試験区 } & \multirow{2}{*}{$\begin{array}{l}\text { 葉数 } \\
\text { (枚) }\end{array}$} & \multirow{2}{*}{$\begin{array}{c}\text { 葉面積 } \\
\left(\mathrm{cm}^{2}\right)\end{array}$} & \multicolumn{3}{|c|}{ 生体重（g） } & \multicolumn{3}{|c|}{ 乾物重 $(\mathrm{g})$} & \multicolumn{3}{|c|}{ 乾物率（\%） } & \multirow{2}{*}{$\begin{array}{l}\text { 比葉面積 } \\
\left(\mathrm{cm}^{2} \cdot \mathrm{g}^{-1}\right)\end{array}$} \\
\hline & & & 葉 & 茥 & 根 & 葉 & 茥 & 根 & 葉 & 茥 & 根 & \\
\hline $500 \mathrm{ppm}$ & 5.9 & 1,150 & 29.9 & 37.0 & 29.9 & 3.53 & 1.83 & 1.03 & 11.8 & 4.9 & 3.4 & 327 \\
\hline $1,000 \mathrm{ppm}$ & 5.8 & 1,070 & 27.8 & 36.8 & 26.1 & 3.35 & 1.83 & 0.97 & 12.0 & 5.0 & 3.7 & 319 \\
\hline 無施用 & 5.9 & 969 & 25.1 & 33.0 & 22.0 & 2.86 & 1.62 & 0.78 & 11.4 & 4.3 & 3.6 & 340 \\
\hline
\end{tabular}

\footnotetext{
${ }^{\mathrm{z}} 2003$ 年 3 月 22 日に調査した
} 


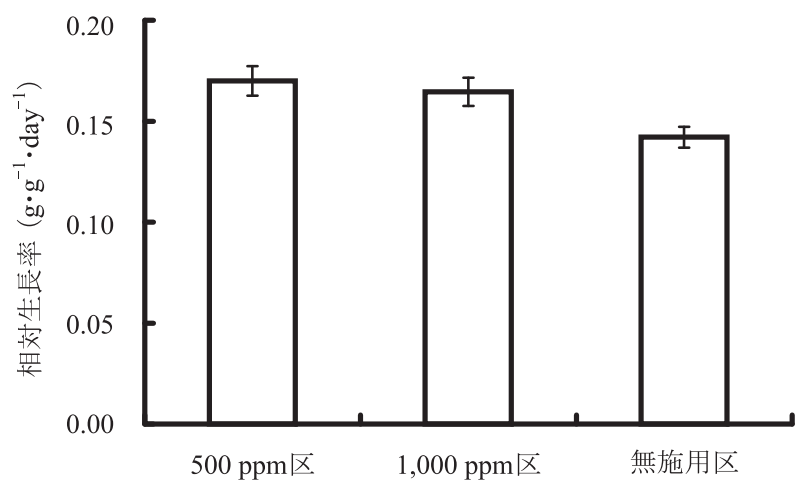

第 2 図二酸化炭素施用がキュウリ乾物重の相対生長率に及 ぼす影響

垂直線は標準誤差（n=5）を示す

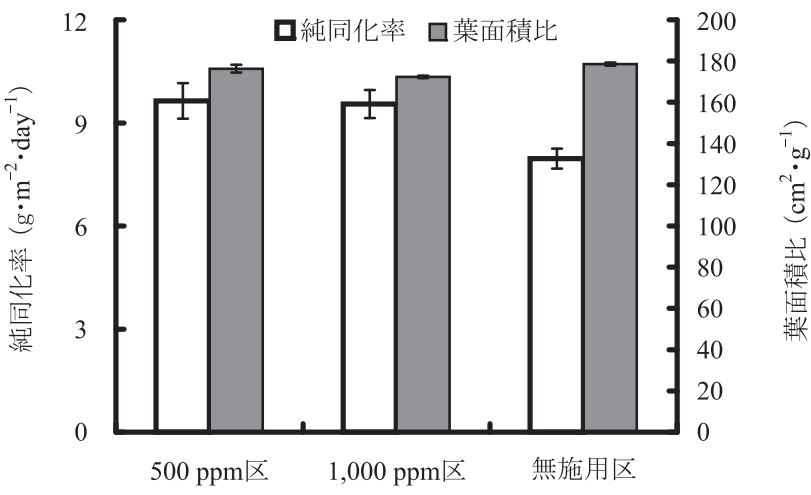

第 3 図二酸化炭素施用がキュウリの純同化率と葉面積比に 及ぼす影響

垂直線は標準誤差（n=5）を示す

区をわずかに上回った（第2図）.

葉面積比は $1,000 \mathrm{ppm}$ 区がわずかに低く, 純同化率は $500 \mathrm{ppm}$ 区が $1,000 \mathrm{ppm}$ 区をわずかに上回り, 両区は無施 用区より高かった(第3 図).

\section{考察}

キュウリの果実収量に対する二酸化炭素施用効果は高 く，無施用区に対して 1,000 ppm 区は 35\%，500 ppm 区は 50\%増収した。菅原ら（1978）は，トマトの養液栽培で, 栽植密度を通常の 2 倍に相当する 17 株・3.3 $\mathrm{m}^{-2}$ にするこ とにより密植と二酸化炭素施用の相乗効果が現れ, 果実収 量が飛躍的に向上することを報告している. 本試験でも栽 植密度を 417 株・ $\mathrm{a}^{-1}$ と通常より密植にし，さらに子蔓を 1 本伸長させて新葉を常に確保して葉面積を増加させたこと が，光合成による二酸化炭素消費量を増長させて無施用区 に打ける二酸化炭素の不足を引き起こしたと考兄られ，こ のことが本試験に扣いて二酸化炭素施用効果が顕著に現れ た要因と推察された.

また，現状のキュウリに対する二酸化炭素施用基準を想 定した $1,000 \mathrm{ppm}$ 区に対して, 換気中にも低濃度で二酸化
炭素施用を行った $500 \mathrm{ppm}$ 区では上物収量, 総収量ともに $15 \sim 16 \%$ 多かった. 幼植物を使用した試験でも，相対生長 率は $500 \mathrm{ppm}$ 区が $1,000 \mathrm{ppm}$ 区をわずかに上回り，乾物生 産量が多かった，相対生長率は，純同化率と葉面積比に分 解することができ，純同化率は括よその乾物生産速度す なわち光合成速度を示すと考光られている（安井・本多， 1977）。 500 ppm 区は，葉面積比抒よび純同化率ともに $1,000 \mathrm{ppm}$ 区をわずかに上回っており，1,000ppm 区に比べ て光合成が促進され，総量として物質生産量が多かったこ とを示唆している.

Slack・Hand（1986）は，1月まきキュウリに対して二酸 化炭素施用濃度を変えて栽培し, 収穫開始後 4 週間の果実 収量は二酸化炭素濃度を $400 \mathrm{ppm}$ から $1,000 \mathrm{ppm}$ に高める ことによって約 30\%増加したものの，1,600 ppm まで高め ても $1,000 \mathrm{ppm}$ と差が無く, $1,000 \mathrm{ppm}$ を最適濃度とした。 この場合, 二酸化炭素施用時間は, 日の出後〜日没までの 長時間にわたるもので，各区同一であった。 これに対して 著者らの試験では $500 \mathrm{ppm}$ 区と $1,000 \mathrm{ppm}$ 区では二酸化炭 素施用時間が異なっており，これが両試験で結果が異なっ た要因と考兄られる。本試験に扔いて，晴天日の 2003 年 2 月 5 日の $1,000 \mathrm{ppm}$ 区では温室内二酸化炭素濃度が二酸化 炭素施用中止後急激に低下し，270 ppm にまで低下した。 11 時〜 14 時 30 分までの室内の平均二酸化炭素濃度は, $1,000 \mathrm{ppm}$ 区が $330 \mathrm{ppm}$ と低かったのに対して, $500 \mathrm{ppm}$ 区 では $560 \mathrm{ppm}$ と高く，この間 $500 \mathrm{ppm}$ 区では $1,000 \mathrm{ppm}$ 区 を上回る物質生産が行われたと考兄られる（第 1 図）.

伊東（1970，1971）は，施設内では通常の換気回数であ る $20 \sim 30$ 回・ $\mathrm{h}^{-1}$ では換気中でも二酸化炭素は不足してお り, 強い風が連続して施設内に入り込むか，光が弱まって 作物の同化作用が低下しない限り，午後 $2 \sim 3$ 時頃まで 二酸化炭素が低濃度の状態で続くとしている. 河野 (1987) は, 強制換気時でも室内の二酸化炭素濃度が外気より $35 \mathrm{ppm}$ 低下したことを，Slack・Hand（1985）も施設内で は換気中でも二酸化炭素濃度が大気中濃度より低下寸るこ とを報告しており，本試験のように晴天日には換気中でる 二酸化炭素濃度が大気濃度を下回ることは一般的なことと 考光られる.

すなわち， $1,000 \mathrm{ppm}$ 区では施用中はキュウリの光合成 が促進されたものの, 施用中止後に二酸化炭素濃度は大気 濃度より低下して光合成速度が低下したのに対して, $500 \mathrm{ppm}$ 区ではその間でも二酸化炭素施用により光合成が 促進され，総量として物質生産量が $1,000 \mathrm{ppm}$ 区より多く なったものと推察され，これが $500 \mathrm{ppm}$ 区が $1,000 \mathrm{ppm}$ 区 より増収した主因と考兄られる。

一方，試験期間中の二酸化炭素施用量は，500 ppm 区で は長時間施用したにもかかわらず $1,000 \mathrm{ppm}$ 区より少な かった。キュウリは高温・高湿度環境下で光合成が促進さ れて物質生産量が増加し（崎山ら，2001），増収することか ら換気時間が短く, 特に外気温が低い $12 \sim 3$ 月の換気量は 
少ない. 本試験の二酸化炭素施用期間は 12 月 19 日〜 3 月 10 日の厳寒期であったため, 内張りカーテンは 10 時 30 分 もしくは 11 時 30 分まで閉じて拈り，また日中の天空の開 閉温度は $29^{\circ} \mathrm{C}$ と高いことから, 内張りカーテンおよび天 空が開く時間が短く, 栽培中の換気回数は $3 \sim 5$ 程度と推 定される. 第 1 図に示した 2003 年 2 月 5 日に颃いて換気回 数を 3 とし，二酸化炭素の室外への流出量を推定すると $500 \mathrm{ppm}$ 区は $534 \mathrm{~g}$ に対して 1,000 ppm 区は $706 \mathrm{~g}$ となり, $500 \mathrm{ppm}$ 区では $1,000 \mathrm{ppm}$ 区より二酸化炭素の室外への流 出量が少なかったものと考えられた.

以上のように, キュウリの促成栽培において，500 ppm もしくは $1,000 \mathrm{ppm}$ を維持するよらに二酸化炭素を施用す ることによって，果実収量は無施用に対して 39〜55\%増 加した。 また，換気中も含めて二酸化炭素濃度 $500 \mathrm{ppm}$ を 目標に 7 時間施用する方法は, 同 $1,000 \mathrm{ppm}$ で 3 時間施用 するのに比べてキュウリの増収効果が高く, 一方では二酸 化炭素施用量が少ない, 費用対効果の高い効率的な施用法 であった。

\section{摘 要}

キュウリの促成栽培において，ガラス室内の二酸化炭素 濃度 $500 \mathrm{ppm}$ 長時間施用と同 $1,000 \mathrm{ppm}$ 短時間施用が，果 実収量に及ぼす影響を明らかにするととともに，その経済 性評価を行った。二酸化炭素施用により上物収量は無施用 より $39 〜 55 \%$ 増加した。 二酸化炭素施用に伴う経費を差 し引いた収益は, 無施用に比べ, $1 \mathrm{a}$ 当たり $5.8 \sim 9.6$ 万円 増加した. $500 \mathrm{ppm}$ 長時間施用は，1,000 ppm 短時間施用に 比べて増収効果が高いとともに，二酸化炭素施用量が少な かった。

\section{引用文献}

池田英男. 1996. 用水と培養液の調整. p. 142. 日本施設園 芸協会編. 最新養液栽培の手引き. 誠文堂新光社. 東京. 板木利隆. 1983. 施設園芸・装置と栽培技術. p. 205-214. 誠文堂新光社. 東京.
伊東 正. 1970. そ菜栽培に拈ける作物群落内の炭酸ガス 濃度低下. 園学雑. 39: 185-192.

伊東 正. 1971. 施設園芸に拈ける炭酸ガス増与とその問 題点. 農及園. 46: 245-250.

伊東 正. 1973. 疏菜の生育・生理に及ぼす炭酸ガス環境 の影響. 千葉大園学特報. 7: 3-14, 47-60, 75-97.

伊東 正. 1977. 施設園芸に打ける炭酸ガス施用技術. 農 及園. 52: 199-205.

Kamp, P. G. and G. J. Timmerman. 2004. コンピューターによ る温室環境の制御（中野明正・細野達夫・東出忠桐・ 高市益行・島地英夫訳). p. 49-55, 74-79, 154-159. 日 本施設園芸協会監修．誠文堂新光社．東京.

河野徳義. 1987. 促成栽培トマトの生育に伴ら換気八ウス の気象特性打よび $\mathrm{CO}_{2}$ 濃度の変化. 農業気象. 43: 15-20.

大須賀隆司. 2003. 二酸化炭素制御. p. 170-177. 日本施設 園芸協会編. 五訂版施設園芸ハンドブック．日本施設 園芸協会. 東京.

崎山 一・壇 和弘・今田成雄・宇田川雄二. 2001。高温 条件下の高湿度がキュウリ幼植物の生育, 蒸散, 養分 吸収, 乾物生産に及ぼす影響. 千葉農総研報. 1: 25-34.

Slack, G. and D. W. Hand. 1985. The effect of winter and summer $\mathrm{CO}_{2}$ enrichment on the growth and fruit yield of glasshouse cucumber. J. Hort. Sci. 60: 507-516.

Slack, G. and D. W. Hand. 1986. The effects of propagation temperature, $\mathrm{CO}_{2}$ concentration and early post-harvest night temperature on the fruit yield of January-sown cucumbers. J. Hort. Sci. 61: 303-306.

菅原真治・武井昭夫・伊藤克己．1978．養液栽培卜マトの 生産安定に関する研究（第 3 報）栽植密度と炭酸ガス 施用効果. 園学要旨. 昭 53 春: 262-263.

渡辺庄一・上浜竜雄. 1976. $\mathrm{CO}_{2}$ 施用によるキュウリ越冬 栽培八ウス内の濃度変化. 農及園. 51: 1045-1046.

安井秀夫・本多藤雄. 1977. 野菜の生育制御に関する生態 学的研究 I 野菜の生長解析. 野菜試報 C. 3: 15-50. 